\title{
The Crisis and Spiritual Identity from a Humanistic Approach
}

\author{
Mehmet Aslan \\ 'Hëna e Plotë' Beder University \\ Tirana/ Albania \\ maslan@beder.edu.al
}

\section{DOI:10.5901/mjss.2014.v5n22p464}

\begin{abstract}
Research conducted on understanding of spirituality and identity through faith or religion regardless of their origin or name has been a vast area of academic studies, besides scanted fruitful outcomes are perceived as more studies are inclined towards the subject in recent years. On the other hand, in today's world individuals are suffering from not only material crisis but also spiritual crisis that are having impacts on identity. The moments of crisis are desperate times that may require desperate measures; however such unwary steps may cause problems on identity, spirit, and self as resulting in crisis on important components of an individual. In order to avoid setbacks and inauspiciousness, faith or beliefs in a divine power are to be studied with their problem solving aspects in moments of crisis. Our perception of psychology and the way we use it in dealing with crisis of different types through generating positive psychology is delved as to understand the new course of psychology in this regard. This study together with literature written on the subject aims to investigate the correlation between crisis and well-being of individuals and their identities as well as the impact of religion on identity in solving personality problems.
\end{abstract}

Keywords: Spirituality and Identity, Spiritual Crisis, Setbacks and Inauspiciousness, Divine Power

\section{Introduction}

Psychology, as a positive subjective experience of science has been -for many years- restricted and described as a devotee of prevention from pathological illnesses, especially when the inquiries for life are arisen together with senses of despair and pessimism, as well as barrenness and meaningless of life. The dominance of pathology resulted in a model of human being that is lack of positive concepts like hope, wisdom, creativity, future mindedness, courage, spirituality, responsibility, and perseverance which are also essential for one`s well-being. Such values were ignored or defined as mere transformations of authentic negative impulses. Thus, in this study it is also aimed to depict the nowadays changed course of psychology in order to understand above mentioned abstract concepts as to find solutions to spiritual problems through the lens of humanistic approaches and religious values that may be of assistance in overcoming with crisis and help individuals to reach psychological well-being.

\section{Generating Positive Psychology}

Psychologists, since foundation of APA in 1940 have exclusively scant information on pathology in terms of reaching a life worth of living, but since the inquiry was centered on corporal well-being, they brought up some valuable data in understanding how people can survive or endure adverse conditions. 3 decades of research have shown that an optimistic explanatory style (ie, attributing negative outcomes to factors that are temporary and specific, rather than to factors that are persistent and pervasive) is associated with better mental and physical health, academic achievement, athletic performance, and performance in many career domains (Hershberger, 2005). However, psychologists have very limited cumulative data on how normal people flourish in peaceful, tranquil conditions. "Psychology has, since World War II, become a science largely about healing..."This almost exclusive attention to pathology neglects the fulfilled individual and thriving community." (Seligman at. al, 2000) On the other hand, the aim of positive psychology is depicted as: "... to begin to catalyze a change in the focus of psychology from preoccupation only with repairing the worst things in life to also building positive qualities. "(Seligman at. al, 2000) At this point, we are presented with individual and group level of positive psychology. For individual level, it's about positive traits as in capacity for love and vocation, courage, forgiveness, originality, future mindedness, spirituality, high talent, and wisdom. At the group level it is about civic virtues and the institutions that move them toward better citizenship. The field of psychology at the subjective level is categorized into three: 
"in the past, well-being, contentment, and satisfaction, for the future, hope and optimism, in the present, flow and happiness." (Seligman at. al, 2000)

\section{Crisis, Spiritual Identity and Religion}

The articles scanted in this study are to serve the same purpose, but with different approaches and methodologies. The question of self in terms of identity through conventional and transpersonal perspectives (Mac Donald, D. A. 2009), complexity of spiritual being or human being, in other words are we spiritual entities wearing the garment of flesh on our bones or human beings with our spiritual entities (Mac Donald, D. A. 2009), conceptual framework is presented suggesting that religion provides a distinct setting for identity exploration and commitment through offering ideological, social, and spiritual contexts (King, P. E. 2003), the relationship between identity and faith development in undergraduates from a private, Catholic university and a public college (Gebelt, J. L. et. al, 2009) are given in the articles either explicitly or implicitly. A very different perspective is given in the article written by Charles W. Calomiris in which the points of intersection between spirituality and financial crises are presented (Calomiris, C. W. 2009).

Two of the studies had their research applied to specific group of people. King's article is based on the research applied to adolescents and suggests that the religious context promotes a sense of identity that transcends the self and promotes a concern for the social good and that religious institutions provide unique settings for adolescent identity formation (King, P. E. 2003). The other one is applied to a collegiate context, higher informational identity style scores are depicted together with higher normative style scores which indicate different measurements and scales in terms of stronger faith, identity styles, and values of religious impacts through which Identity distress was related to greater questioning of beliefs and expectation of future change in those beliefs (Gebelt, J. L. et. al, 2009).

One of the most striking similarities among the studies conducted on the same issue is that they all value and care about the fact that spirituality and identity have been subject to many researches and more and more studies are emphasizing the importance of religious impacts on spirituality and identity. As a part of the swelling interest, attention to the relation of spirituality to identity and identify formation has also seen somewhat of a rise (Mac Donald, D. A. 2009). Currently within the social sciences there seems to be a revival of interest in religion and spirituality (King, P. E. 2003). From the days of Erikson's $(1963,1968)$ first explorations of identity, issues of spirituality and/or religiosity have played a central role in identity theories (Hoare, 2002). (Gebelt, J. L. et. al, 2009). The role of faith which has been underestimated for long time is brought to the core of study in Gebelt's article in which the importance is mentioned as followed: Surprisingly, however, in spite of the theoretical and methodological importance of faith in identity models, faith development continues to be studied primarily as a distinctly separate area of research from identity, though in recent years this has begun to change (Gebelt, J. L. et. al, 2009). King's article also claims that the role of religion has been neglected and left unexplored as it was pushed behind the curtains by Freud's referrals. Freud (1928/1961) referred to "religion as a universal obsessional neurosis" (p. 43) and "a mere illusion, derived from human wishes," (p. 31). Although sub-disciplines such as psychology of religion and religious education have developed a substantial body of work, many other areas of psychology, especially developmental psychology, have until recently left religion and spirituality relatively unexplored (Benson, Roehlkepartain, \& Rude, this issue; Donelson, 1999; Weaver et al., 1998). This special issue, along with an emerging body of developmental research and publications, suggests that on the cusp of the 21st century, religion and spirituality are recognized as viable domains of study (King, P. E. 2003). On the other hand, Macdonald's article mentions the function of faith or religion through the definition of identity and spirituality which provides a different perspective on the issue and helps us understand better within four overlapping points of confusion where it starts to get more blur rather than comprehensive. Spirituality, namely (a) its relation to religion and religiousness, (b) its ontological status (i.e., is spirituality real or merely a product of biopsychosocial processes?), (c) its dimensionality (e.g., is it a single construct or is it multidimensional?), and (d) its relation to and place within personality psychology (i.e., is it best understood to be a part of personality or is it something different?), (Mac Donald, D. A. 2009).

The article written by Calomiris is strikingly different than the others as it is mostly focused on the financial crisis caused by political mistakes on mortgage system that caused great depression on people and seem to be sinking to the bottom day by day, however his direct referrals to the Bible as a holy book in terms of providing spiritual solutions to the financial crisis attracted a distinctive perception on the issue. Crises are moments when circumstances force us to make important decisions. But why should our individual or collective decisions in response to financial crises have a spiritual component? (Calomiris, C. W. 2009). The very fact that other articles are mostly based on scientific measurements on a topic like spirituality and identity is quite interesting as Calomiris` article is mostly the opposite. The Bible, after all, is itself largely a crisis chronicle. It might be best described as a recounting of a sequence of political, economic, and personal crises, which often coincide, and in which spiritual insights or errors prompted people to make important decisions, for better or worse, 
about their personal and societal futures. Adam and Eve, Moses, Gideon, David, Solomon, Jesus, and Paul, just to name a few, were all faced with crises that they had to manage (Calomiris, C. W. 2009).

The comprehension or definition of spirituality and identity could not be provided without religious impacts on both as it plays a key role in the moments of crisis and personality development through which individual traits may construct a much healthier society. The studies -contrary to the Freudian and his followers' referrals- are mainly focused on the idea that sense of religion is essential. Even empirical studies conducted by Gebelt on young adults (collegiate context) reflect a spirituality scale with these results: The current study found that identity and religiosity are related in ways consistent with identity theory. As hypothesized, having a more informational identity style related to having stronger faith and engaging in more spiritual questing. Participants with higher informational scores reported more questioning of their beliefs, placing greater value on doubting those beliefs, and expecting those beliefs to change in the future (Gebelt, J. L. et. al, 2009). King's article is even more devoted on claiming the role of religion. At its best the religious context provides an anchor as an ideological, social, and spiritual community that serves to ground a young person through the sometimes turbulent waters of adolescence (King, P. E. 2003). As Einstein summarizes in short: "Science without Religion Is Lame, Religion without Science Is Blind."

\section{Conclusion}

What we may surmise from generally depicted methodologies and practices of positive psychology is that we have quite little knowledge on positive approach and its advantages in reaching achievement in terms of amplified or nurtured talent of the actual human potential. We infer the very essence of the actual potential of human being through comprehension of positive approach in terms of providing concrete solutions to crisis of identities and spiritualities of today's societies; also referred to as "the science of happiness," positive psychology is striving to be rigorous and evidence based in its endeavor to identify interventions that promote mental health and quality of life. (Hershberger, P. J. at. al, 2005) In our schools we may possibly adopt this approach as it is showing parallel values of enriching individuals, and concentrating on their positive values rather than negativities as they may buffer against mutual understanding, dialog, tolerance, forgiveness, love, and such universal values which are essential in reaching a universal tranquility.

Furthermore, many studies as observed in this article indicate common results; the importance of faith or belief in a divine power is essential in overcoming with crisis. Generating positive psychology in this regard would make it easier to match the need for belief and its contribution to problems of spirituality.

\section{References}

Benson, P. L. (1997). Spirituality and the adolescent journey. Reclaiming Children and Youth, 5, 206-209.

Calomiris, C. W. (2009) A Spiritual Response to the Financial Crisis? Making Decisions for the Really Long Run, Columbia University and NBER.

Donelson, E. (1999). Psychology of religion and adolescents in the United States: Past to present. Journal of Adolescence, 22, 187-204.

Erikson, E. H. (1963). Childhood and Society. New York: Norton.

Erikson, E. H. (1968). Identity: Youth and crisis. New York: Norton.

Freud, S. (1961). The future of an illusion (J. Strachey, Trans.). New York: Norton. (Original work published 1928)

Gebelt, J. L. \& Thompson S. K. \& Meile K. A (2009) Identity Style and Spirituality in a Collegiate Context, Identity: An International Journal of Theory and Research, 9:219-232, 2009.

Hershberger, P. J. (2005). Prescribing Happiness: Positive Psychology and Family Medicine.

Hoare, C. H. (2002). Erikson on development in adulthood: New insights from the unpublished papers. New York: Oxford University Press.

King, P. E. (2003) Religion and Identity: The Role of Ideological, Social, and Spiritual Contexts, Applied Developmental Science 2003, Vol. 7, No. 3, 197-204.

MacDonald, D. A. (2009) Identity and Spirituality: Conventional and Transpersonal Perspectives, University of Detroit Mercy Detroit, MI, USA.

Seligman, M. E. P. \& Csikszentmihalyi M. (2000) American Psychologist (Positive Psychology, an Introduction).

Weaver, A. J., Kline, A. E., Samford, J. A., Lucas, L. A., Larson, D. B.,\&Gorsuch, R. L. (1998). Is religion taboo in psychology? A systematic analysis of research on religion in seven major American Psychological Association journals: 1991-1994. Journal of Psychology and Christianity, 17, 220-232 